\title{
Notes from an intentional farm community
}

\author{
Book review by Gregory Zimmerman * \\ Lake Superior State University
}

\section{Review of The Community-Scale Permaculture Farm: The $D$ Acres Model for Creating and Managing an Ecologically Designed Education Center, by Josh Trought. (2015). Published by Chelsea Green, White River Junction, Vermont. Available as paperback; 416 pages. Publisher's website: http://www.chelseagreen.com/the- communityscale-permaculture-farm}

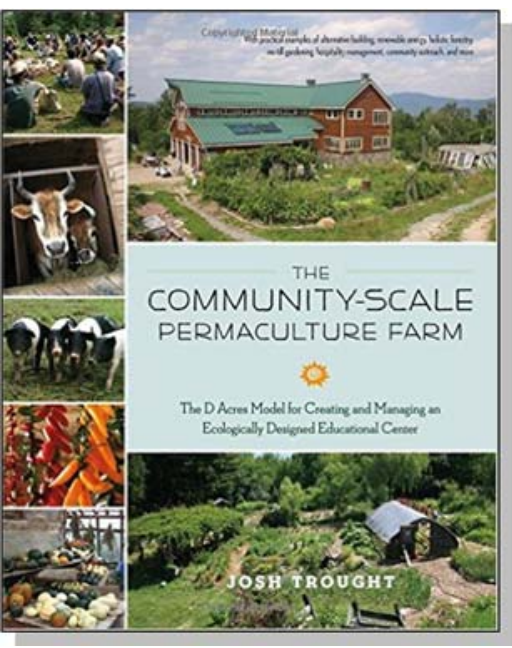

Submitted June 15, 2015 / Published online August 6, 2015

Citation: Zimmerman, G. (2015). Notes from an intentional farm community [Book review]. Journal of Agriculture, Food Systems, and Community Development, 5(4), 199-201. http://dx.doi.org/10.5304/jafscd.2015.054.009

Copyright (C) 2015 by New Leaf Associates, Inc.

$\mathrm{M}$ any of us have projects in which we build community around food. Community gardens, food hubs, farm-to-school, farmers' markets, expanding nutrition assistance, policy research and advocacy, and other such projects enhance nutrition, help build the local food system, and increase capacity of local communities. We pick a few aspects of "community" and a few aspects of "food" and tie them together. Josh

* Gregory Zimmerman, Professor of Biology, Lake Superior State University; 650 West Easterday; Sault Sainte Marie, Michigan 49783 USA; gzimmerman@LSSU.edu

Gregory Zimmerman is a professor of Biology at Lake Superior State University, where he teaches in the area of ecology, biostats and epidemiology. His research includes sustainable local communities, food systems, and environmental conservation. He and his family have a small, diverse farm on which they grow produce for the local farmer's market, CSA customers, and local restaurants.
Trought has taken many aspects of community and many aspects of food and tied them together in D Acres Farm and written about his experiences with this large project in the book The Community Scale Permaculture Farm.

D Acres defies easy categorization. It's a group of people living together on a farm, growing much of their own food and sharing their knowledge. Trought uses the term "intentional community" and "land-based service movement," since "collective" and "commune" bring to mind too many distracting concepts and images. He is looking to do no less than develop a new model for small farming, an alternative in the sense of ag practices but also an alternative to the family farm for those not part of a farming family. Revenue is derived from sales of farm-derived products, educational programs, and grant funds. This book summarizes the experiences of building and 
operating this entity; this review is about the book, not directly about the entity it describes.

As someone who works in the local food system, both as a researcher and a participant, I read the book looking for lessons learned I could put into practice. I was also curious about such an ambitious project: how did it come together and how does it work? At 395 pages this is a long book, but Trought's conversational style of writing makes it an easy read. In the introduction he states that his purpose in writing the book is so readers "can use this model as a platform for their own innovation and creative living." So it's intended to be part inspiration and part how-to.

The first several chapters set the stage for the $\mathrm{D}$ Acres project, beginning with a litany of woes about the current food system. These woes include loss of farmland to urban sprawl, nonsustainable farming practices, disconnection from the source of our food, devaluation of food and the labor required to produce it, loss of community connections and engagement, and the disadvantages of capitalism. Even land trusts and academia are not immune from criticism. Trought then provides some history of responses to those problems, such as the back-to-the-land movement typified by Helen and Scott Nearing, religious communities, and most recently, the permaculture approach. He presents these examples to show how the D Acres project was built on the lessons from these previous attempts to overcome the problems with the modern mainstream agricultural industry.

Getting more specific about the D Acres environs, chapter 3 describes the sense of place for the White Mountains of New Hampshire where D Acres was built from the Trought family farm. Chapter 4 lays out the history of the transition from family farm to the present D Acres farm. He explains some missteps based on the naiveté of a group of people who wanted to start an alternative farming community. It's always fun for me to read about people new to farming learning all about what it really takes to build a successful farm. In this case, the experiences went beyond learning all the pieces that go together to make a farm and included the development of an organization around the ideals of a group of people coming together to build an intentional community.
After these introductory chapters, Trought describes the daily activities of the farm in Chapter 5. One gets a picture of the hard physical work of farming, the collaboration of the members of the D Acres community and the consensus decisionmaking approach they use, and how D Acres engages with the broader local community. The remainder of the book describes specific parts of how this project works. Chapters about collaborative decision-making and governance provide good insight into the way the project operates, but they are a bit vague on specifics. The chapter about the farm's revenue stream illustrates the challenges of managing costs and multiple revenue streams, and highlights the nature of the $\mathrm{D}$ Acres farm as educational center as much as farm. Chapters about animals, buildings, and water and energy provide some good, practical, experience-based advice. Sometimes the advice is very specific, if commonly known, but one could tell the members literally learned from scratch (advice such as don't put away wet hay because it can start a fire). For example, the descriptions of their use of oxen and the challenges that presents are quite detailed. The chapter about buildings is quite lengthy but illustrates the farm's whole-systems view, from siting to materials selection to layout, construction, and maintenance, and the challenges from using nonstandard building techniques such as cob (clay, sand, and straw).

The chapters about gardening and food harvesting and preserving offer additional practical how-to advice while showing how they are able to provide food for the residents and guests of the farm. These descriptions illustrate the thorough analysis they do and the very deliberate nature of all their work. That theme is especially evident in the chapters about "The Farm Ecology" and their forestry work, which also highlights their work with oxen.

Chapters about community outreach, cottage industry, and marketing and promotion round out the description of this wide-ranging venture. These chapters also present some advice others can use in their work in promoting specific aspects of building community around food.

The final chapter, "Ideas to Come," provides reflection about how D Acres can advance and 
further its goal of building a lasting "eco-village" in which a community's members can work together to provide for the community's own needs.

Trought makes it clear that this approach is not recommended for everyone and that he does not consider it the only solution to the problems with the current industrial ag model.

While the book was an enjoyable read, there were some parts I found distracting. Many chapters start out with a lengthy philosophical treatise. These passages frame the project and provide insight into the basis of $\mathrm{D}$ Acres, but they could be briefer. The writing is not overwrought, but neither is it always to the point. Some word choices are a bit puzzling. Instead of simply saying that wood chips have a high carbon-to-nitrogen $(\mathrm{C}: \mathrm{N})$ ratio that slows down microbial activity, he writes about the "entropic condition" of wood chips (although later he specifically mentions ideal C:N ratios).

I found a few factual inconsistencies distracting as well. In a few places, Trought comes close to equating soil organic material and the mineral component of silt. Also in one passage he likens the process of drilling a water well to a hydrau- lically fractured petroleum well. Although both involve a drill rig, they are quite different, to say the least!

As far as lessons learned, I would have liked to have more information about the decision-making process they use. Specific farm advice is readily available; how to get a group of people to work together in this kind of project and at this level of commitment is not.

Overall, this book is a worthwhile read and provides good insight into this specific example of what I am now learning is a growing set of these types of communities. Although I promised that this review would be about the book and not about the project it describes, I can't help making one comment on projects such as D Acres. While reading this book, I also read an article in Smithsonian magazine about new suburbs incorporating working farms into their built environment. All I can say is that compared to that approach, D Acres and the other eco-village/deliberate communities somehow seem to be more honest attempts to reconnect us more broadly with our sources of sustenance (although again, they are not for everyone). 